\title{
A comparison of the in vitro genotoxicity of anticancer drugs idarubicin and mitoxantrone ${ }^{\star \star}$
}

\author{
Janusz Błasiak ${ }^{\bowtie}$, Ewa Gloc and Mariusz Warszawski \\ Department of Molecular Genetics, University of Łódż, S. Banacha 12/16, 90-237 Łódż, Poland
}

Received: 10 September, 2001; revised: 15 Januray, 2002; accepted: 2 February, 2002

Key words: idarubicin, mitoxantrone, DNA damage, DNA repair, comet assay, oxidative DNA damage, DNA methylation

\begin{abstract}
Idarubicin is an anthracycline antibiotic used in cancer therapy. Mitoxantrone is an anthracycline analog with presumed better antineoplastic activity and lesser toxicity. Using the alkaline comet assay we showed that the drugs at 0.01-10 $\mu \mathrm{M}$ induced DNA damage in normal human lymphocytes. The effect induced by idarubicin was more pronounced than by mitoxantrone $(P<0.001)$. The cells treated with mitoxantrone at $1 \mu \mathrm{M}$ were able to repair damage to their DNA within a 30-min incubation, whereas the lymphocytes exposed to idarubicin needed $180 \mathrm{~min}$. Since anthracyclines are known to produce free radicals, we checked whether reactive oxygen species might be involved in the observed DNA damage. Catalase, an enzyme inactivating hydrogen peroxide, decreased the extent of DNA damage induced by idarubicin, but did not affect the extent evoked by mitoxantrone. Lymphocytes exposed to the drugs and treated with endonuclease III or formamidopyrimidine-DNA glycosylase (Fpg), enzymes recognizing and nicking oxidized bases, displayed a higher level of DNA damage than the untreated ones. 3-Methyladenine-DNA glycosylase II (AlkA), an enzyme recognizing and nicking mainly methylated bases in DNA, increased the extent of DNA damage caused by idarubicin, but not that induced by mitoxantrone. Our results indicate that the induction of secondary malignancies should be taken into account as side effects of the two drugs. Direct strand breaks, oxidation and methylation of the DNA bases can underlie the DNA-damaging effect of idarubicin, whereas mitoxantrone can induce strand breaks and modification of the bases, including oxidation. The observed in normal lymphocytes much lesser genotoxicity of mitoxantrone compared to idarubicin should be taken into account in planning chemotherapeutic strategies.
\end{abstract}

\footnotetext{
${ }^{\star}$ Presented at the 8th International Symposium on Molecular Aspects of Chemotherapy, September, 2001, Gdańsk, Poland.

This work was supported by grants: 505/652 (J.B.) and 505/653 (E.G.) from the University of Łódź.

${ }^{凶}$ Please send all correspondence to Janusz Błasiak at the above address; phone (48 42) 635 4334, fax (48 42) 635 4484, e-mail januszb@biol.uni.lodz.pl
}

Abbreviations: AlkA, 3-methyladenine-DNA glycosylase II; AP-site, apurinic or apyrimidinic site; DAPI, 4',6-diamidino-2-phenylindole; Endo III, endonuclease III; Fpg, formamidopyrimidine-DNA glycosylase; PBS, phosphate-buffered saline. 
Genotoxicity of anticancer drugs to normal cells is one of the most serious problems of chemotherapy due to the possibility of inducing secondary malignancies. Although a precise definition of "genotoxicity" is elusive, there is no doubt that DNA damage plays an important role in most mechanisms underlying the action of anticancer drugs interacting with DNA. It is therefore an imperative task in chemotherapy to determine the DNA-damaging effect of these drugs on normal cells [1].

Anthracyclines are widely used as anticancer drugs. The first anthracycline antibiotics, daunorubicin and doxorubicin (Fig. 1A), originally isolated from Streptomyces sp., were found to have antineoplastic activity in the early 60s. All anthracyclines consist of an aglycone ring coupled with an aminosugar and they can produce a wide range of biological effects. The planar ring can intercalate be-

\section{A}

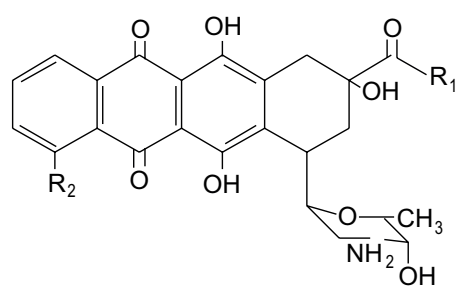

in DNA [4-6]. Anthracyclines can undergo one-electron reduction and form oxygen free radical intermediates. In the presence of oxygen and metals, an anthracycline can be reduced to a semiquinone radical, which can form a superoxide radical, which, in turn, can be converted to a hydroxyl radical [7-9]. These free radicals can induce membrane lipid peroxidation, DNA strand scission and direct oxidation of purine and pyrimidine bases, thiols and amines. Thus, they may contribute to cardiotoxicity of anthracyclines, because heart tissue is essentially devoid of glutathione peroxidase which converts superoxide radicals back to oxygen [10, 11].

Idarubicin (4-demethoxy-daunorubicin) is a synthetic analog of daunorubicin (Fig. 1A). Deletion of the methoxy group increases lipophilicity of idarubicin compared with that of daunorubicin and doxorubicin, enhances

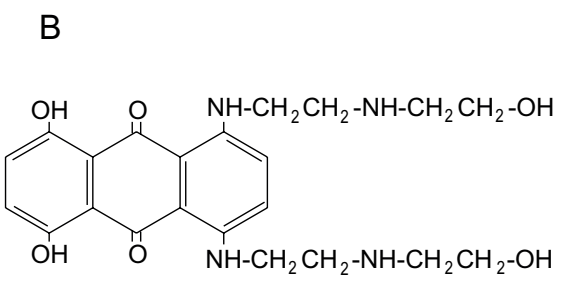

Figure 1. Structures of anthracycline antibiotics: idarubicin, doxorubicin and daunorubicin (A) and mitoxantrone (B).

tween DNA base pairs and the aminosugar moiety can interact with negatively charged phosphate groups in the DNA major groove $[2,3]$. The intercalation can cause changes in the shape of DNA helix, interfering with transcription and replication. Anthracyclines can also inhibit the activity of topoisomerase II, an enzyme introducing double-strand breaks its uptake into tumor cells and may increase its binding to DNA. Idarubicin has orphan drug designation for acute myelogenous leukemia, acute lymphoblastic leukemia in children, chronic myelogenous leukemia and myelodysplastic syndrome. Idarubicin forms free radicals to a lesser extent than other anthracyclines; this may account for its re- 
duced cardiotoxicity [12]. The dose of anthracyclines and other anticancer drugs sufficient to kill tumor cells often is toxic to normal tissue and leads to side effects myelosuppression, neutropenia, cardiomyopathy, nausea, vomiting and induction of secondary tumors.

Mitoxantrone (1,4-dihydroxy-5,8-bis-[(2-[(2hydroxyethyl)amino] ethyl)amino]-9,10-anthracenedione) is an anthracycline analog with better antineoplastic activity and less toxicity than doxorubicin. It is an anthracenedione and anthracycline analog (Fig. 1B). The anthracenedione class of synthetic anticancer compounds lack the amino sugar moiety and tetracyclic A ring of anthracyclines, but retain the planar polycyclic aromatic ring structure and thus the potential to intercalate between DNA bases [13]. Mitoxantrone inhibits topoisomerase II and displays a significantly reduced potential to form free radicals compared to anthracyclines [14]. It is used for the treatment of breast cancer, prostate cancer, leukemia and lymphoma.

Single cell electrophoresis (the comet assay) is a sensitive method for detecting DNA strand breaks in individual cells [15]. It also reveals alkali-labile sites in DNA, when run in alkaline conditions. The alkaline comet assay has been also used for several years as a method for quantitation of oxidized bases in DNA [16].

In the present work we compared the DNA-damaging potential of idarubicin and mitoxantrone in normal human peripheral blood lymphocytes using the alkaline comet assay. Cell viability and the kinetics of repair of DNA damage were also measured. Since both idarubicin and mitoxantrone are known to produce free radicals [17-19], we tried to assess the role of oxidative DNA damage in genotoxicity of the drugs by employing three enzymes: catalase, endonuclease III (Endo III) and formamidopyrimidine-DNA glycosylase (Fpg). Catalase transforms hydrogen peroxide into water and its effect may indicate whether $\mathrm{H}_{2} \mathrm{O}_{2}$ can play a role in DNA-da- maging activity of idarubicin and mitoxantrone [20]. Endo III induces, near oxidized pyrimidines in DNA, strand breaks which can be detected by the comet assay [16]. Fpg is involved in the first step of the base excision repair removing specific modified bases from DNA so as to create an apurinic or apyrimidinic site (AP-site), which is subsequently cleaved by its AP lyase giving a gap in the DNA strand [21]. The gap can be detected by the comet assay. The enzyme excises mainly 2,6-diamino-4-hydroxy-5- $N$-methyl formamidopyrimidine [22] and 7,8-dihydro8-oxo-2' deoxyguanine (8-oxo-G) [16, 23]. Due to the presence of methyl groups in its structure, idarubicin can be considered a potential alkylating agent. The role of alkylated bases in cancer induction is well documented so it was thought worth checking the ability of the two drugs to generate methylated bases in DNA. To do so we employed another enzyme, 3-methyladenine-DNA glycosylase II (AlkA), which has a broad substrate specificity including alkylated purines: 7-methylguanine (7-MeGua) and 3-methyladenine (3-MeAde), $O^{2}$-alkylpyrimidines, hypoxanthine [24, 25].

\section{MATERIALS AND METHODS}

Chemicals. Idarubicin was obtained from Pharmacia \& Upjohn (Milan, Italy). Mitoxantrone was purchased from Jelfa (Jelenia Góra, Poland). Tris, RPMI 1640 medium without glutamine, agarose, low melting point agarose, phosphate-buffered saline (PBS), catalase and DAPI (4',6-diamidino-2-phenylindole) were obtained from Sigma Chemicals Co. (St. Louis, MO, U.S.A.). Gradisol L was obtained from Aqua Medica (Łódź, Poland). Endo III, Fpg and AlkA were gifts from Dr. B. Tudek and Prof. J. Kuśmierek of the Institute of Biochemistry and Biophysics, Polish Academy of Sciences (Warsaw, Poland).

Lymphocyte isolation. Blood was obtained from young, healthy, nonsmoking donors. Peripheral blood leukocytes were isolated by 
centrifugation in a density gradient of Gradisol L (15 min, $280 \times g$ ). Viability of the cells was measured by the trypan blue exclusion staining and was about $99 \%$. Final concentration of the lymphocytes was adjusted to $1-3 \times 10^{5}$ cells $/ \mathrm{ml}$ by adding RPMI 1640 to the single cell suspension.

Cell treatment. Idarubicin and mitoxantrone were taken from their stock solutions ( 0.5 and $4 \mathrm{mM}$, respectively) in RPMI 1640 and added to the suspension of lymphocytes to give final concentrations in the range of 0.01-10 $\mu \mathrm{M}$. To control cells only RPMI 1640 was addedd. To examine DNA damage, the lymphocytes were incubated with the chemicals for $1 \mathrm{~h}$ at $37^{\circ} \mathrm{C}$. Each experiment included a positive control, which was hydrogen peroxide at $20 \mu \mathrm{M} . \mathrm{H}_{2} \mathrm{O}_{2}$ produced pronounced DNA damage, which resulted in comet tail moment of 80-120 $\mu \mathrm{m}$ (not shown).

Cell viability. Viability of lymphocytes was determined by trypan blue exclusion analysis. Lymphocytes were incubated with either drug at the concentration range of $0.01-50 \mu \mathrm{M}$ for $1 \mathrm{~h}$ at $37^{\circ} \mathrm{C}$, washed and resuspended in RPMI 1640 . An equal volume of $0.4 \%$ trypan blue reagent was added to the cell suspension and the percentage of viable cells was evaluated under a field microscope. Assays were performed in triplicate.

DNA repair. To examine DNA repair, the cells after treatment as well as control samples were washed and incubated in fresh, drug-free RPMI 1640 medium. Aliquots of the suspension were taken immediately and 15 , 30, 60 and 120 min later. Placing the samples in an ice bath stopped the repair incubation.

Comet assay. The comet assay was performed under alkaline conditions essentially according to the procedure of Singh et al. [15] with some modifications [16, 26] as described previously [27]. A freshly prepared suspension of lymphocytes in $0.75 \%$ low-melting point agarose dissolved in PBS was cast onto microscope slides precoated with $0.5 \%$ normal melting agarose. The cells were then lysed for $1 \mathrm{~h}$ at $4^{\circ} \mathrm{C}$ in a buffer consisting of $2.5 \mathrm{M} \mathrm{NaCl}$,
$100 \mathrm{mM}$ EDTA, 1\% Triton X-100 and $10 \mathrm{mM}$ Tris, $\mathrm{pH}$ 10. After lysis, slides were placed in an electrophoresis unit, DNA was allowed to unwind for $40 \mathrm{~min}$ in electrophoretic solution containing $300 \mathrm{mM} \mathrm{NaOH}$ and $1 \mathrm{mM}$ EDTA, $\mathrm{pH}>13$. Electrophoresis was conducted at $4^{\circ} \mathrm{C}$ (the temperature of the running buffer not exceeding $12^{\circ} \mathrm{C}$ ) for $30 \mathrm{~min}$ at an electric field strength of $0.73 \mathrm{~V} / \mathrm{cm}(30 \mathrm{~mA})$. The slides were then neutralized with $0.4 \mathrm{M}$ Tris, $\mathrm{pH} 7.5$, stained with $2 \mu \mathrm{g} / \mathrm{ml}$ DAPI and covered with cover slips. To prevent additional DNA damage, all steps were conducted under a dimmed light or in the dark.

Catalase treatment. The suspension of lymphocytes in $0.75 \%$ LMP agarose was spread onto microscope slides and lysis was performed as described above. After lysis and washing with Tris/EDTA buffer, $50 \mu \mathrm{l}$ of idarubicin or mitoxantrone at concentrations from 0.05 to $50 \mu \mathrm{M}$ with $250 \mathrm{U} / \mathrm{ml}$ catalase was spread onto the agarose layer, covered with a cover slip and incubated for $1 \mathrm{~h}$ at $37^{\circ} \mathrm{C}$. The slides were then processed as described above.

Endo III treatment. After lysis the slides were washed three times in a buffer comprising $40 \mathrm{mM}$ Hepes/KOH, $0.1 \mathrm{mM} \mathrm{KCl}, 0.5 \mathrm{mM}$ EDTA and $0.2 \mathrm{mg} / \mathrm{ml}$ bovine serum albumin, $\mathrm{pH} 8$, then the agarose was covered with $25 \mu \mathrm{l}$ of either buffer or endonuclease III at $1 \mu \mathrm{g} / \mathrm{ml}$ in buffer, sealed with a cover glass and incubated for $30 \mathrm{~min}$ at $37^{\circ} \mathrm{C}$. Further steps were performed as described above.

Fpg treatment. Lymphocytes were treated with idarubicin and lysed in agarose on slides, which were then washed 3 times in Fpg buffer comprising $70 \mathrm{mM}$ Hepes/KOH, $0.1 \mathrm{M} \mathrm{KCl}, 2$ $\mathrm{mM}$ EDTA and $0.26 \mathrm{mg} / \mathrm{ml}$ bovine serum albumin, $\mathrm{pH}$ 7.6, drained and the agarose covered with $25 \mu \mathrm{l}$ of either buffer or Fpg at $1 \mu \mathrm{g} / \mathrm{ml}$ in buffer, sealed with a cover glass and incubated for $30 \mathrm{~min}$ at $37^{\circ} \mathrm{C}$. Further steps were performed as described above.

AlkA treatment. Lymphocytes were incubated with idarubicin, lysed and washed 3 times in AlkA buffer containing $70 \mathrm{mM}$ 
Hepes/KOH, 1 mM EDTA, 1 mM $\beta$-mercaptoethanol and $5 \%$ glycerol, $\mathrm{pH}$ 7.6. The slides were then drained and the agarose was covered with $25 \mu$ l of either buffer or AlkA at 1 $\mu \mathrm{g} / \mathrm{ml}$ in buffer and processed as described above.

Comet analysis. The slides were examined at 200 magnification in an Eclipse fluorescence microscope (Nikon, Tokyo, Japan) attached to a COHU 4910 video camera (Cohu, Inc., San Diego, CA, U.S.A.) equipped with a UV filter block containing an excitation filter (359 nm) and barrier filter (461 nm) and connected to a personal computer-based image analysis system, Lucia-Comet v. 4.51 (Laboratory Imaging, Praha, Czech Republic). Fifty images were randomly selected from each sample and the comet tail moment (a product of fraction of DNA in tail and tail length) was measured. Two parallel tests with aliquots of the same sample were performed, each for a total of 100 cells, and the mean comet tail moment was calculated. The comet tail moment is positively correlated with the level of DNA breakage in a cell [28]. The mean value of the tail moment in a particular sample was taken as an index of DNA damage in this sample.

Statistical analysis. All the values in this study were expressed as mean S.E.M. If no significant differences between variations were found, as assessed by Snedecor-Fisher test, the differences between means were evaluated by applying Student's $t$-test. Otherwise, the Cochran-Cox test was used. The data were analyzed using STATISTICA (StatSoft, Tulsa, OK, U.S.A.) statistical package.

\section{RESULTS}

\section{Cell viability}

The results of cell viability tests after incubation of human lymphocytes with idarubicin or mitoxantrone at different concentrations (Fig. 2) show that both tested compounds caused a concentration-dependent decrease in cell viability. There were no differences $(P>0.05)$ between the viability of the cells in the presence of either compound at concentrations up to $10 \mu \mathrm{M}$, i.e. the maximal concentration of the drugs used in further experiments. Viability of the lymphocytes at $10 \mu \mathrm{M}$ drug concentration was about $81 \%$. Above $10 \mu \mathrm{M}$ idarubicin evoked a more pronounced decrease in viability of the lymphocytes than mitoxantrone $(46 \%$ cells viable with idarubicin at $100 \mu \mathrm{M} v$ s. $70 \%$ for mitoxantrone; $P<0.001)$.

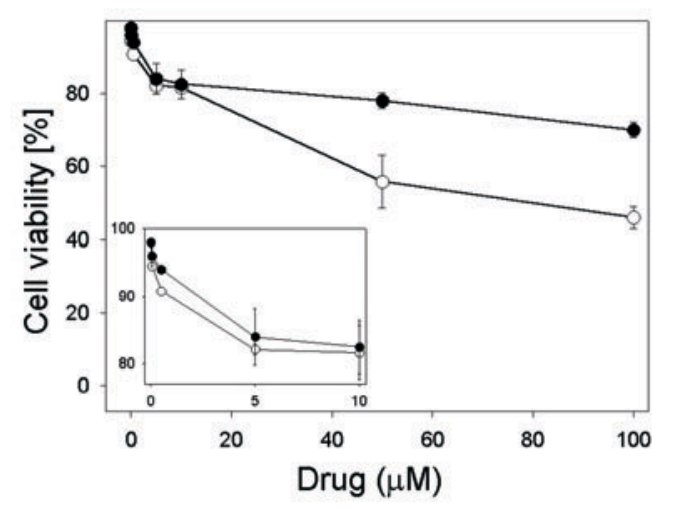

Figure 2. Effect of idarubicin (O) and mitoxantrone (O) on viability of human lymphocytes measured by the trypan blue exclusion method.

Each point is the mean of three experiments; error bars denote S.E.M. The viability in the drug concentration range $0-10 \mu \mathrm{M}$ is displayed in the inset.

DNA damage. Figure 3 shows the mean tail moments of lymphocytes after exposure for 1 $\mathrm{h}$ to idarubicin or mitoxantrone at various concentrations. Both drugs evoked a dose-dependent increase in the tail moment. At all concentrations applied the increase induced by idarubicin was much more pronounced than that caused by mitoxantrone $(P<0.001)$.

DNA repair. Figure 4 shows the comet tail moments of the lymphocytes exposed to idarubicin or mitoxantrone at $1 \mu \mathrm{M}$ immediately after exposure as well as 30, 60, 120 and 180 min thereafter. In all cases, the comet tail moment of control cells was constant, indicating that preparation and subsequent process- 


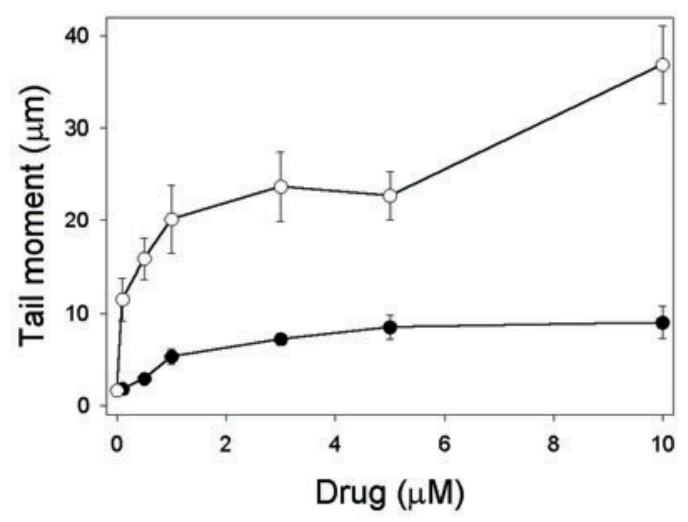

Figure 3. Mean comet tail moment of human lymphocytes exposed for $1 \mathrm{~h}$ at $37^{\circ} \mathrm{C}$ to idarubicin ( () or mitoxantrone (O).

Data from two parallel tests (100 cells in each) were pooled and mean \pm S.E.M. calculated. Error bars denote S.E.M.

ing of the lymphocytes did not introduce significant damage to their DNA. The cells exposed to $20 \mu \mathrm{M}$ hydrogen peroxide (positive control) were able to recover within the repair incubation time of $60 \mathrm{~min}$ (not shown). The

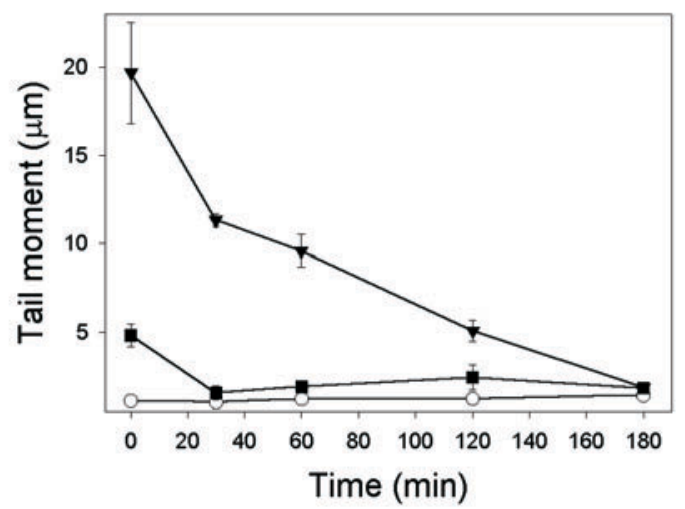

Figure 4. Time course of repair of DNA damage in human lymphocytes treated with idarubicin at $1 \mu \mathrm{M}(\nabla)$ or mitoxantrone at $10 \mu \mathrm{M}(\square)$ compared with untreated control $(O)$.

The number of cells scored for each treatment was 100 . Error bars denote S.E.M.

lymphocytes exposed to idarubicin at all tested concentrations repaired damage to their DNA within 180 min post-treatment incubation. The lymphocytes exposed to mito- xantrone needed a much shorter period to remove the DNA damage - the repair was complete after $30 \mathrm{~min}$.

Catalase treatment. Figure 5 shows the mean comet tail moments for the lymphocytes treated with idarubicin or mitoxantrone at indicated concentrations in the presence or absence of catalase. Catalase significantly reduced the tail moment of lymphocytes exposed to idarubicin at $0.05 \mu \mathrm{M}(P<0.05)$ and $0.5 \mu \mathrm{M}(P<0.001)$, whereas the enzyme did not significantly $(P>0.05)$ affect the level of DNA damage caused by mitoxantrone.

Endo III treatment. Figure 6 presents the mean comet tail moment of the lymphocytes

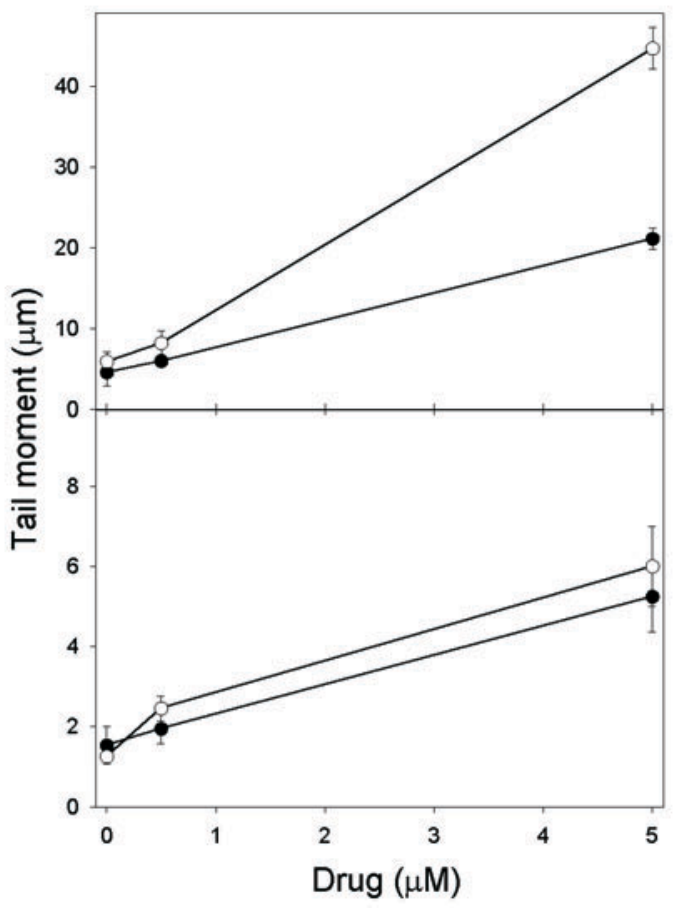

Figure 5. Mean comet tail moment of human lymphocytes exposed for $1 \mathrm{~h}$ at $37^{\circ} \mathrm{C}$ to idarubicin (upper panel) or mitoxantrone (lower panel) with (O) or without $(O)$ subsequent treatment with catalase at $250 \mathrm{U} / \mathrm{ml}$.

Data from two parallel tests (100 cells in each) were pooled and mean \pm S.E.M. calculated. Error bars denote S.E.M.

exposed for $1 \mathrm{~h}$ at $37^{\circ} \mathrm{C}$ to idarubicin or mitoxantrone with post-treatment with Endo III, compared with the cells not treated with the enzyme. It can be seen that lymphocytes 


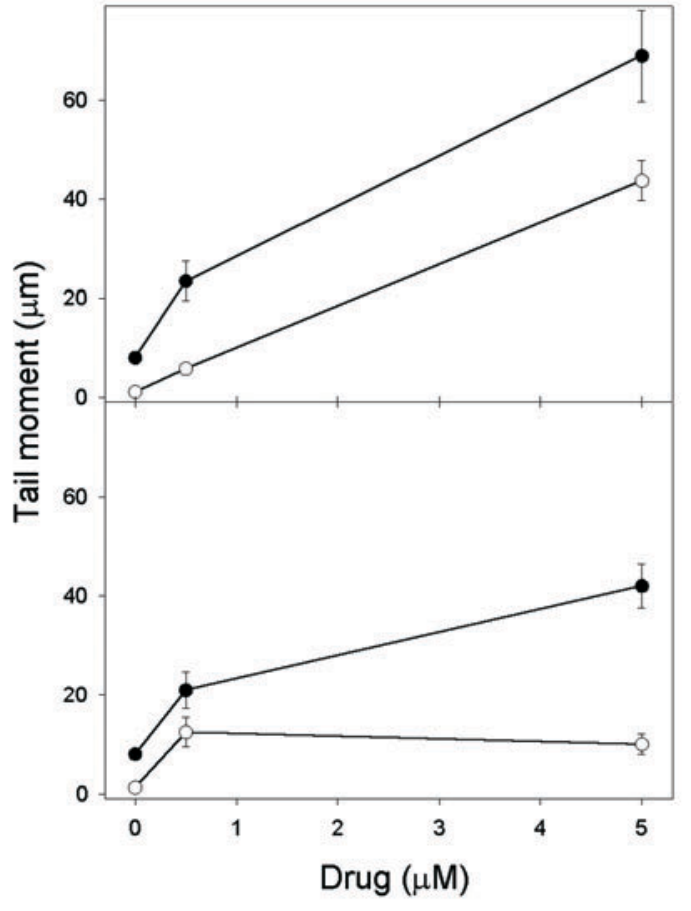

Figure 6. Mean comet tail moment of human lymphocytes exposed for $1 \mathrm{~h}$ at $37^{\circ} \mathrm{C}$ to idarubicin (upper panel) or mitoxantrone (lower panel) with (O) or without $(O)$ subsequent treatment with endonuclease III (Endo III) at $1 \mu \mathrm{g} / \mathrm{ml}$.

Data from two parallel tests (100 cells in each) were pooled and mean \pm S.E.M. calculated. Error bars denote S.E.M.

exposed to idarubicin or mitoxantrone, after treatment with Endo III, showed a significantly greater tail moment than the cells untreated with the enzyme.

Fpg treatment. The mean comet tail moments for the lymphocytes exposed to idarubicin or mitoxantrone with subsequent treatment with Fpg are shown in Fig. 7. Fpg significantly increased the tail moment of lymphocytes exposed to either drug.

AlkA treatment. Figure 8 shows the mean comet tail moments of the lymphocytes exposed to idarubicin or mitoxantrone with post-treatment with AlkA. AlkA significantly increased the tail moment of lymphocytes exposed to idarubicin at $5 \mu \mathrm{M}(P<0.001)$, but the enzyme did not influence the level of DNA damage induced by mitoxantrone.

\section{DISCUSSION}

Anthracycline antibiotics are widely used in cancer therapy and idarubicin represents one of the drugs of the second generation of those compounds. Mitoxantrone was synthesized as a result of searching for anthracycline analogs with better antineoplastic activity and/or lesser toxicity than that of parent compounds. The main aim of our study was to compare the genotoxic potential of these two drugs towards normal cells. The ability to induce DNA damage in non-cancerous cells may underlie one of the most serious side effects evoked by anticancer drugs - induction of secondary malignancies. The results obtained indicate that idarubicin and mitoxantrone can produce a significant increase in the tail moment of the comets of human lymphocytes. This in-

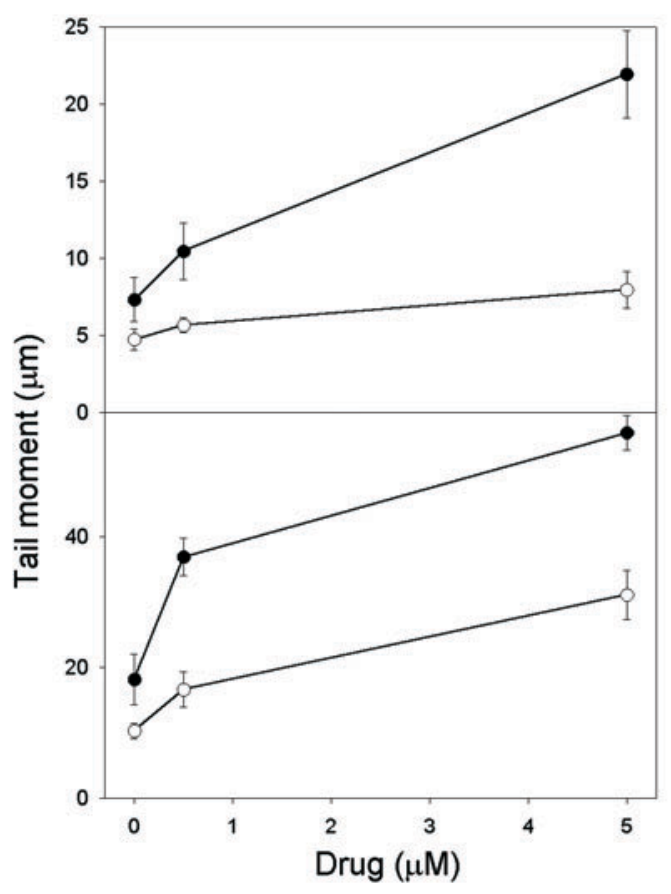

Figure 7. Mean comet tail moment of human lymphocytes exposed for $1 \mathrm{~h}$ at $37^{\circ} \mathrm{C}$ to idarubicin (upper panel) or mitoxantrone (lower panel) with (O) or without (O) subsequent treatment with formamidopyrimidine-DNA glycosylase (Fpg) at $1 \mu \mathrm{g} / \mathrm{ml}$.

Data from two parallel tests (100 cells in each) were pooled and mean \pm S.E.M. calculated. Error bars denote S.E.M. 


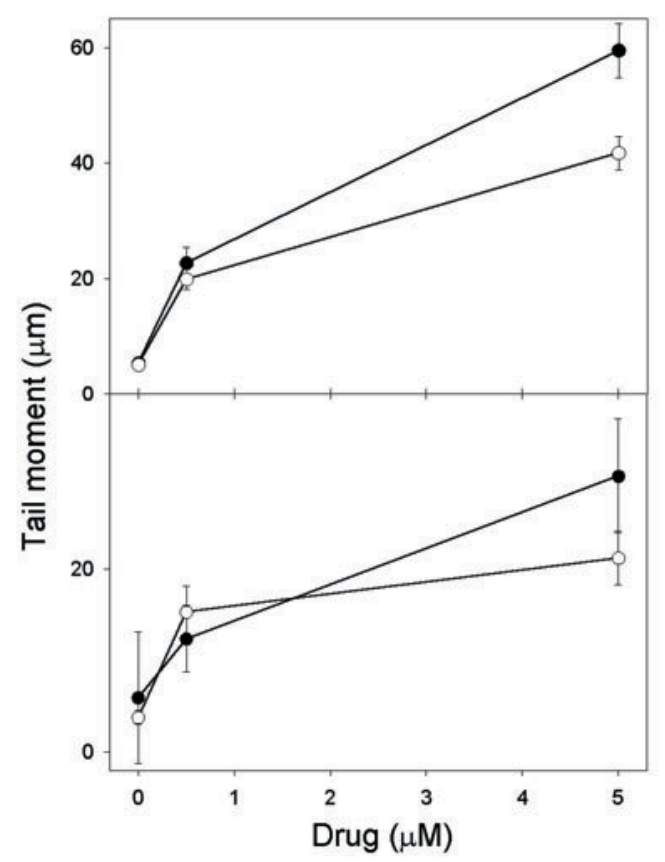

Figure 8. Mean comet tail moment of human lymphocytes exposed for $1 \mathrm{~h}$ at $37^{\circ} \mathrm{C}$ to idarubicin (upper panel) or mitoxantrone (lower panel) with (O) or without $(O)$ subsequent treatment with 3-methyladenine-DNA glycosylase II (AlkA) at $1 \mu \mathrm{g} / \mathrm{ml}$.

Data from two parallel tests (100 cells in each) were pooled and mean \pm S.E.M. calculated. Error bars denote S.E.M.

crease may be due to the induction of DNA damage in the form of strand breaks or alkali-labile sites by either of the two drugs. The extent of DNA damage caused by idarubicin was much more pronounced (even about 4-fold at the highest concentration used, $10 \mu \mathrm{M}$ ) than that induced by mitoxantrone, which indicates, in the context of our work, that mitoxantrone has much lesser ability than idarubicin to induce DNA damage in normal cells and, therefore, to induce secondary malignancies during chemotherapy. This should be taken into account in planning a chemotherapeutic strategy.

In the cell viability study, we showed that neither idarubicin at the concentration range up to $10 \mu \mathrm{M}$ nor mitoxantrone were cytotoxic for normal human lymphocytes. This was confirmed in the DNA repair study, in which the cells exposed to $1 \mu \mathrm{M}$ mitoxantrone were able to recover within $30 \mathrm{~min}$ and the lymphocytes treated with idarubicin at the same concentration needed $180 \mathrm{~min}$ to remove damage to their DNA.

The observed increase in the tail moment of the lymphocytes exposed to either drug can be due to direct induction of DNA strand breaks and/or generation of such modifications in DNA, which can be transformed into strand breaks in the alkaline conditions of the comet assay. The former can originate from stabilization of topoisomerase II, which can introduce DNA strand breaks when interacts for prolonged time and from the action of free radicals which can be generated by idarubicin and mitoxantrone [29]. The latter may follow from various modifications of the DNA bases or sugar-phosphate backbone introduced by the drugs or their by-products, including reactive oxygen species. We deduced that one of them, hydrogen peroxide, was involved in generation of DNA damage induced by the drugs (Fig. 5). By itself $\mathrm{H}_{2} \mathrm{O}_{2}$ is relatively nonreactive toward DNA [30]. Most of the hydrogen peroxide-mediated DNA damage is due to the production of hydroxyl radical ( $\mathrm{OH}$ ) via events such as the Fenton reaction [31, 32] or the metal-independent Fenton reaction [33]. Although the reduction of hydrogen via the Fenton reactions is the most commonly considered pathway for its decomposition, oxidation of $\mathrm{H}_{2} \mathrm{O}_{2}$ may yield perhydroxyl radical $\left(\mathrm{HO}_{2}\right)$ which can generate alkoxyl radicals. Reactions of these radicals with DNA bases initially yield unstable radical intermediates centered on DNA. These intermediates are the immediate precursors for DNA base damage [34]. Therefore all reactive species derived from hydrogen peroxide can induce DNA damage, which can be in the form of strand breaks or oxidative modifications of DNA bases.

In order to further assess the role of oxidative base modifications in the observed genotoxicity of idarubicin and mitoxantrone, we employed enzymes involved in the base excision repair to recognize and remove specifi- 
cally oxidized bases from DNA: Endo III and formamidopyrimidine-DNA glycosylase, Fpg. The significant $(P<0.05)$ difference in the tail moments of the lymphocytes post-treated and untreated with Endo III in the absence of the drugs arose probably from endogenous oxidative damage to DNA pyrimidines as well as from oxidative damage to DNA introduced during isolation and processing of the cells. We showed that Endo III treatment of lymphocytes exposed to either drug evoked a pronounced increase in the tail moment of the cells (Fig. 6), suggesting that the drugs induced oxidized pyrimidines. We also showed that Fpg, an enzyme recognizing mainly 7,8-dihydro-8-oxo-2' deoxyguanine (8-oxo-G), introduced strand breaks to DNA treated with idarubicin or mitoxantrone (Fig. 7) - this can serve as further evidence for oxidative DNA damage being caused by these drugs. Fpg can also detect methylated bases in DNA. To check whether methylation is involved in genotoxic action of idarubicin and mitoxantrone, we used 3-methyladenine-DNA glycosylase II, AlkA, an enzyme recognizing and nicking methylated bases in DNA. Lymphocytes treated with idarubicin and the enzyme displayed a greater tail moment than the cells untreated with AlkA (Fig. 8), thus methylation might contribute to DNA-damaging effect of the drug. Idarubicin has a methyl group in its structure but at present we do not know how it can be transferred onto DNA bases and whether this process underlies the observed increase in the activity of AlkA, because this enzyme can be also engaged in the recognition of oxidized bases in DNA. In all cases the extent of the DNA damage recognized and modified by the enzymes was greater for idarubicin than for mitoxantrone.

Our results are in agreement with those reported for double and single strand breaks induced by the two drugs [35, 36]. Idarubicin, like other anthracyclines, can be reduced to form semiquinone radical, which can be finally converted to hydroxyl radical. There are unequivocal reports on the role of mitoxantrone in oxidative stress - it can display both anti- and pro-oxidative properties [37, 38]. Some of our results support the thesis on pro-oxidative action of mitoxantrone (Figs. 3, $6,8)$, but others, like the lack of effect of catalase (Fig. 5) and AlkA (Fig. 8) on the extent of DNA damage induced by the drug, suggest its antioxidative activity. This point should be addressed in future research on the genotoxicity of mitoxantrone in normal cells, but the results of our present study suggests that, when the difference between the expected anticancer outcome as well as between general toxic side effects of idarubicin and mitoxantrone does not matter, the latter drug should be used because on its application there is lesser probability of induction of secondary malignancies in normal tissue.

\section{R E F E R E N C E S}

1. Gentile, J.M., Rahimi, S., Zwiesler, J., Gentile, G.J. \& Ferguson, L.R. (1998) Effects of selected antimutagens on the genotoxicity of antitumor agents. Mutat. Res. 402, 289-298.

2. Kellogg, G.E., Scarsdale, J.N. \& Fornari, F.A. (1998) Identification and hydropathic characterization of structural features affecting sequence specificity for doxorubicin intercalation into DNA double-stranded polynucleotides. Nucleic Acids Res. 26, 4721-4732.

3. Zhang, H.M. \& Li, N.Q. (2000) Electrochemical studies of the interaction of adriamycin to DNA. J. Pharm. Biomed. Anal. 22, 67-73.

4. Tewey, K.M., Rowe, T.C., Yang, L., Halligan, B.D. \& Liu, L.F. (1984) Adriamycin-induced DNA damage mediated by mammalian DNA topoisomerase II. Science 226, 466-468.

5. Schneider, E., Hsiang, Y. \& Liu, L.F. (1990) DNA topoisomerases as anticancer drug targets. Adv. Pharmacol. 21, 149-183.

6. Bridewell, D.J., Finlay, G.J. \& Baguley, B.C. (1997) Differential actions of aclarubicin and 
doxorubicin: The role of topoisomerase I. Oncol. Res. 9, 535-542.

7. Abraham, R., Basser, R.L. \& Green, M.D. (1996) A risk-benefit assessment of anthracycline antibiotics in antineoplastic therapy. Drug Safety 15, 406-429.

8. Faure, H., Mousseau, M., Cadet, J., Guimier, C., Tripier, M., Hida, H. \& Favier, A. (1998) Urine 8-oxo-7,8-dihydro-2-deoxyguanosine vs. 5-(hydroxymethyl)uracil as DNA oxidation marker in adriamycin-treated patients. Free Radical Res. 28, 377-382.

9. Stathopoulos, G.P., Malamos, N.A., Dontas, I., Deliconstantinos, G., Perrea-Kotsarelis, D. \& Karayannacos, P.E. (1998) Inhibition of adriamycin cardiotoxicity by 5 -fluorouracil: A potential free oxygen radical scavenger. Anticancer Res. 18, 4387-4392.

10. Falcone, G., Filippelli, W., Mazzarella, B., Tufano, R., Mastronardi, P., Filippelli, A., Berrino, L. \& Rossi, F. (1998) Cardiotoxicity of doxorubicin: Effects of 21-aminosteroids. Life Sci. 63, 1525-1532.

11. Samelis, G.F., Stathopoulos, G.P., Kotsarelis, D., Dontas, I., Frangia, C. \& Karayannacos, P.E. (1998) Doxorubicin cardiotoxicity and serum lipid increase is prevented by dextrazoxane (ICRF-187). Anticancer Res. 18, 3305-3309.

12. Platel, D., Pouna, P., Bonoron-Adele, S. \& Robert, J. (1999) Comparative cardiotoxicity of idarubicin and doxorubicin using the isolated perfused rat heart model. Anticancer Drugs 10, 671-676.

13. George, J.W., Ghate, S., Matson, S.W. \& Besterman, J.M. (1992) Inhibition of DNA helicase II unwinding and ATPase activities by DNA-interacting ligands. Kinetics and specificity. J. Biol. Chem. 267, 10683-10689.

14. Linassier, C., Barin, C., Calais, G., Letortorec, S., Bremond, J.L., Delain, M., Petit, A., Georget, M.T., Cartron, G., Raban, N., Benboubker, L., Leloup, R., Binet, C.,
Lamagnere, J.P. \& Colombat, P. (2000) Early secondary acute myelogenous leukemia in breast cancer patients after treatment with mitoxantrone, cyclophosphamide, fluorouracil and radiation therapy. Ann. Oncol. 11, $1289-1294$.

15. Singh, N.P., McCoy, T., Tice, R.R. \& Schneider, E.L. (1988) A simple technique for quantitation of low levels of DNA damage in individual cells. Exp. Cell Res. 175, 184-192.

16. Collins, A.R., Duthie, S.J. \& Dobson, V.L. (1993) Direct enzymatic detections of endogenous base damage in human lymphocyte DNA. Carcinogenesis 14, 1733-1735.

17. Fisher, G.R. \& Patterson, L.H. (1991) DNA strand breakage by peroxidase-activated mitoxantrone. J. Pharm. Pharmacol. 43, 65-68.

18. Reszka, K.J., Matuszak, Z. \& Chignell, C.F. (1997) Lactoperoxidase-catalyzed oxidation of the anticancer agent mitoxantrone by nitrogen dioxide radicals. Chem. Res. Toxicol. 10, 1325-1330.

19. Borchmann, P., Hubel, K., Schnell, R. \& Engert, A. (1997) Idarubicin: A brief overview on pharmacology and clinical use. Int. J. Clin. Pharmacol. Ther. 35, 80-83.

20.Duthie, S.J. \& Collins, A.R. (1997) The influence of cell growth, detoxifying enzymes and DNA repair of human hydrogen peroxide-mediated DNA damage (measured using the comet assay) in human cells. Free Radical Biol. Med. 22, 717-724.

21. David-Cordonnier, M.-H., Laval, J. \& O’Neill, P. (2000) Clustered DNA damage, influence on damage excision by XRS5 nuclear extracts and Escherichia coli Nth and Fpg proteins. J. Biol. Chem. 275, 11865-11873.

22. Boiteux, S., Gajewski, E., Laval, J. \& Dizdaroglu, M. (1992) Substrate specificity of the Escherichia coli Fpg protein (formamidopyrimidine-DNA glycosylase): Excision of purine lesions in DNA produced by ionizing 
radiation or photosensitization. Biochemistry 31, 106-110.

23.Tchou, J., Kasai, H., Shibutani, S., Chung, M.H., Laval, J., Grollman, A.P. \& Nishimura, S. (1991) 8-Oxoguanine (8-hydroxyguanine) DNA glycosylase and its substrate specificity. Proc. Natl. Acad. Sci. U.S.A. 88, 4690-4694.

24. Laval, J. (1977) Two enzymes are required for strand incision in repair of alkylated DNA. $N a$ ture 269, 829-832.

25.Tudek, B., VanZeeland, A.A., Kusmierek, J.T. \& Laval, J. (1998) Activity of Escherichia coli DNA-glycosylases on DNA damaged by methylating and ethylating agents and influence of 3 -substituted adenine derivatives. Mutat. Res. 407, 169-176.

26. Klaude, M., Eriksson, S., Nygren, J. \& Ahnstrom, G. (1996) The comet assay: Mechanisms and technical considerations. Mutat. Res. 12, 89-96.

27. Blasiak, J. \& Kowalik, J. (2000) A comparison of the in vitro genotoxicity of tri- and hexavalent chromium. Mutat. Res. 469, 135-145.

28. Ashby, J.A., Tinwell, H., Lefevre, P.A. \& Brown, M.A. (1995) The single cell gel electrophoresis assay for induced DNA damage (comet assay): Measurement of tail length and moment. Mutagenesis 10, 85-90.

29. Hande, K.R. (1998) Clinical applications of anticancer drugs targeted to topoisomerase II. Biochim. Biophys. Acta 1400, 173-184.

30. Shackelford, R.E., Kaufmann, W.K. \& Paules, R.S. (2000) Oxidative stress and cell cycle checkpoint function. Free Radical Biol. Med. 28, 1387-1404.

31. Dizdaroglu, M., Rao, G., Halliwell, B. \& Gajewski, E. (1991) Damage to the DNA bases in mammalian chromatin by hydrogen peroxide in the presence of ferric and cupric ions. Arch. Biochem. Biophys. 285, 317-324.

32. Imlay, J.A., Chin, S.M. \& Linn, S. (1991) Toxic DNA damage by hydrogen peroxide through the Fenton reaction in vivo and in vitro. Science 240, 640-642.

33.Zhu, B.Z., Kitrossky, N. \& Chevion, M. (2000) Evidence for production of hydroxyl radicals by pentachlorophenol metabolites and hydrogen peroxide: A metal-independent organic Fenton reaction. Biochem. Biophys. Res. Commun. 270, 942-946.

34. Termini, J. (2000) Hydroperoxide-induced DNA damage and mutations. Mutat. Res. 450, $107-124$.

35. Capranico, G., Riva, A., Tinelli, S., Dasdia, T. \& Zunino, F. (1987) Markedly reduced levels of anthracycline-induced DNA strand breaks in resistant P388 leukemia cells and isolated nuclei. Cancer Res. 47, 3752-3756.

36. Senkal, M., Tonn, J.C., Schonmayr, R., Schachenmayr, W., Eickhoff, U., Kemen, M. \& Kollig, E. (1997) Mitoxantrone-induced DNA strand breaks in cell-cultures of malignant human astrocytoma and glioblastoma tumors. $J$. Neurooncol. 32, 203-208.

37. Kolodziejczyk, P., Reszka, K. \& Lown, J.W. (1988) Enzymatic oxidative activation and transformation of the antitumor agent mitoxantrone. Free Radical Biol. Med. 5, $13-25$.

38. Novak, R.F. \& Kharasch, E.D. (1985) Mitoxantrone: Propensity for free radical formation and lipid peroxidation - implications for cardiotoxicity. Invest. New Drugs 3, 95-99. 